\title{
Gender Equality for Lao Women: Mining Community's Perspective
}

\author{
NATTAVUD PIMPA \\ College of Management \\ Mahidol University \\ Email: nattavud.pimpa@ rmit.edu.au
}

\begin{abstract}
It is evident that women are largely excluded from sharing of the economic benefits from international mining industry. The gendered impacts of mining industry on women, therefore, is critical. In this paper, the researcher investigates the impact of mining companies on gender equality through the perceptions and life experiences of female workers, members of the community, and their family in a mining community in Lao PDR. Through the analysis of the community perspectives, the study shows that CSR and other economic programs on women employment, social roles, and health promotion can influence the likelihood of sustainable development likelihood by mining companies. The main obstacle for the promotion of gender equality remains work conditions and expected gender roles in the community.
\end{abstract}

Keywords: Gender, Women and Work, CSR, Sustainable Development.

\section{Introduction}

Although the local and international stakeholders expect mining multinational corporations (MNCs) to embrace principles of human rights and eqity, promoting gender equality and workplace diversity, actual practices reflect counter ideologies of gender difference (World Economic Forum, 2017). The structure of mining jobs can potentially discriminate against women participation (Kemp et al, 2011).

At the operational level, women's jobs tend to be concentrated in administrative positions and provision of clerical or domestic services with a similar division in mine sites (Kemp et al, 2011; Hamann, 2004). In many circumstances, women participate in mining industry on a seasonal basis or at time of particular economic difficulty (Jenkins, 2014). This can have negative impacts on family functioning and marriages, as well as on the male workers themselves. Mercier and Gier (2007) describes the lives of female partners of male mine workers as 'silent' partners in the industry whose work is also directly and indirectly exploited by the mining corporation. Domestic role overload, lack of social integration, economic dependency, unpaid work and poor quality of life can lead to greater vulnerability to mental illness (Sharrma, 2010; Pimpa et al, 2015).

When women move beyond the traditional work spaces designated to them by the local cultural, it can be associated with being sexually available (Lahiri-Dutt, 2006). This means that measures aimed at mainstreaming gender issues in the organization, such as policies of equal pay for equal work (Asian Development Bank, 2012) are not effective in facilitating or encouraging equity because they operate within a larger, social framework of rigid gender roles (Hamann, 2004) and gender power inequalities. 
Gender equality for men and women has become a critical issue for all MNCs including those from the mining industry. Scholars such as Hirsh and Lounsbury (1997) and Dashwood (2012) argued that mining MNCs tend not to be able to account for change in organisational behaviour, character, and practices. CSR activities by mining companies should provide development assistance to the host countries. A number of gender issues are inter-connected and cannot be addressed in isolation. Instead, a wider-lens, multistakeholder approach is necessary for CSR activities. While mining companies cannot be sole drivers of change, it is important that they take a proactive approach and look at gender issues from the sustainable development perspective.

\section{Policies on Sustainable Development for Women}

Empowering women and promoting gender equality is crucial to accelerating sustainable development. Ending all forms of discrimination against women and girls is not only a basic human right, but it also has a multiplier effect across all other development areas. (UNDP, 2019).

Sustainable development can only be achieved through long-term investments in economic, human and environmental capital (OECD, 2007). It is argued that incan promote progress in society, we still need to promote sustainable development in order to maintain gender equality at different levels and perspectives. The reasons for not employing women and creating an enabling and empowering workplace for women are not yet clear (Pederson, 2009). Some of the justifications given in favour of women employment are based on biological essentialism which can lead to further stereotyping of men and women and erosion of gender equity. Women are sometimes hired because they are more 'compliant' or cost the company less. These statements reinforce predetermined notions of who women are and what they should be like (Lahiri-Dutt, 2011).

Some mining MNCs have become responsive to gender equality issues and have made commitments towards gender equity through projects in departments devoted to implementing social responsibility (Hamann, 2004). The mining industry can be a considerable motor for development but addressing framework conditions that place women in a disadvantaged position when compared to men is necessary to exploit the full potential benefits of mining for both men and women.

It is reported by WEDO (2008) that most women in the mining sector struggle with the participation in issues related to working rights, standard of work, minimum wages and labour representation. Women in mining often do not have the same access to and control over capital and resources as men or equal rights of power and freedom at work (Jutting et.al, 2008). This is the basic of root problem in gender inequality. Given the lack of understanding on how the impacts of business actions (including CSR) by mining companies, the purpose of this study is not to replicate existing institutional theories (e.g Ruef \& Scott, 1998; Dashwood, 2012), but to understand how integrating two concepts (sustainable development and gender equality) can inform inquiry on the influences of mining companies' CSR approaches.

\section{Why Lao PDR?}

The primary challenges to gender equality are in enabling equal access for women and girls to opportunities and resources, particularly for rural and marginalized women. Illiteracy, poor reproductive and basic health, food insecurity and economic disenfranchisement rank high among development priorities for women (WEDO, 2008).

Despite Lao PDR's high and steady economic growth, averaging 7.8\% GDP over the last decade, poverty and gender inequality remain persistent challenges. Significant progress has been made in reducing poverty from $33.5 \%$ to $23.2 \%$. The gender gap in education has narrowed and Lao PDR has among the higher proportions of women legislators globally at 27.5\% (Pimpa et al, 2015). 
While gender equality is frequently viewed as a social issue, it is also a core economic issue. Improving gender equality and women's participation in the economy could drive additional economic growth. In Mekong countries, achieving equality between women and men could result in a $12 \%$ increase in GDP by 2025 over the business-as-usual trajectory (Woetzel, et al. 2018).

Lao PDR has made steady progress in a number of areas related to gender equality and women's empowerment, and has begun to develop the policies and capabilities to carry out gender mainstreaming. For example, the gender gap in educational enrollment at all three levels has narrowed; maternal and child mortality has dropped significantly; Lao PDR has one of the highest proportions of women in the national parliament - at $27.5 \%$ this is well above the world's average; and the Gender Equality Strategy of Agriculture, Forestry and Rural Development Sector (2016-2025) was developed as an example of efforts to mainstream gender across line ministries. Despite this progress, a number of challenges remain in achieving gender equality and developing the capabilities of the strategies to mainstream gender into policy-making and development planning. Therefore, this issue is truly important for the citizens of Lao PDR.

\section{Research Questions}

- To what extent can a mining company empower local women from the CSR activities?

- How can CSR activities by mining companies be related to the promotion of gender equality?

\section{Research Location}

We conducted this study at Sepon, an open-pit copper and gold-mining operation in Southern Laos. The area is the major investment by Lane Xang Minerals Ltd. (LXML). LXML owns 90 per cent of Sepon in partnership with the government of Laos which owns 10 per cent. Sepon gold project commenced production in 2002; its copper operation commenced in 2005. LXML is a subsidiary of Australian, Chinese and Lao companies.

From 46 villages in this area, the research team conducted several fieldworks at seven villages in Vilabouly district. They include Ban Vangyang, Namkeep, Ban Noonsomboon, Padong, Boungkham, ) Nongkadeang, and Ban Huay Suan.These villages are heavily influenced by the establishment and operation of mining industry. Interestingly, the diversity in socio-linguistic and ethnics among these villages is reported by the Government of Vilabouly district.

\section{Methodology}

The researcher adopted the qualitative approach for this project. At the first stage of this project, the researcher seeks to learn experiences from the community's perspectives. We use qualitative approach, focusing on exploratory approach to understand life experiences of women in the mining community. Because we are interested in the stories from each participant, we selected semi-structured interviews as the key data collection technique. This technique helps the researchers to focus on language use by key informants as well as contextual and relational aspects expressed by the interviewees.

The researcher decided to select participants from seven villages in Southern Laos. At the end, We interviewed 76 participants from seven villages (including workers from mining company, community leaders, family members of the workers, men and women from different ethnic groups). Snowball technique was adopted in the selection of research participants. 62 per cent of the participants are women. Interviews were conducted in Lao, Bru and Phu Tai languages. Transcripts were translated into English and analysed by research team. 


\section{Findings}

\section{Theme 1: Equality through Economic Status}

The participants in this study discussed their work and economic opportunities as the beginning point of discussion. Most of them started working of the lands then move to work for the company. Some may continue their work when mining industry was introduced to the community. Some changed their career from agricultural sector into mining. Relationship between mining and women in the community is tied closely.

When women are employed by the company, it is likely that they will encourage other local women to work with them. Mos of them identify that employment opportunities provide them with opportunities to lead the family, the same way as their male counterparts. From the interviews with various members of the Vilabouly community, we learn that mining MNC can create tremendous economic and life opportunities for women in Vilabouly and those who migrate to work and reside in Vilabouly. This, in return, is good for the company.

"Hiring more women is a good opportunity for the company to learn some lessons through Lao women's perspectives."

With a proper design of gender policies on human resources policies, local Lao women can engage in various types of work and economic opportunities from mining industry. Most women referred to miningrelated work, running a shop or café, being mini-suppler for the mining company, business for workers of the company, skill building programs by mining companies, and skills development activity.

"I have been working as a cleaner for the company and it helps me to plan our family incomes and education for my children."

Although the majority of female labour force in mining is non-technical roles, working for mining company in Vilabouly is perceived as a high-status job for women. Most women who work in mining industry stated that employment from the company provides not only income but also opportunity to engage in various activities provide by the company. Equality can be created by the perception that women can be employed and work at the same level with their male counterparts in this industry. Mining MNC in this study also sets professional development activities for female staff as key elements. For most women, they requested a company to set up a childcare or centre for young children. Most of them raised an issue of the cost of childcare which is far too expensive.

\section{Theme 2: Equality through Social Activities}

Social activities refer to various activities engaging men and women to achieve social aims such as cultural activities, policies, and governance. We found that mining work is not flexible for women to engage in social activities in their community. For instance, when a woman addressed her need to engage in the local public policy hearings, she mentioned that the work seem to be more flexible for men, than women, to engage in such activities. Where there are flexible work practices available there is limited take-up so that the full-time working week is the norm. Most female workers in this study agreed that this is a key barrier or obstacle to them with caring and earning responsibilities.

"If I don't have to work long hour and look after my family after work, I will be able to engage in other activities in the village."

"I am a mother of three young children so I found it is really hard for me to balance my work life and them." 
Women in Vilabouly seem to have different views on traditional male-dominated culture of this industry. Most women are comfortable to play the role of leader in family, with a strong support from their husbands and other family members. Women who earn from mining industry seem to gain status from family and community. Some of them 'switched' roles with their husbands. Some women who work in the mining industry expressed their views that, due to time commitment at work, their husbands will need to play the role of house husband. They also have equal say in family financial issues. These changes in 'roles' must be agreed among family members. The company also starts some activities that create a platform for male househusbands to discuss strategies to support their wives. Although this is not a formal business activity, it raises the profile of the company in the eyes of the community.

"We have a female head of village who supports women to work or establish business in the community. I think she does it because she's a woman and she understand us."

With economic empowerment activities from the industry, women can participate more in political roles in the community. Female participants in this study confirm that when company promotes representation of women in activities, such as the company's micro-finance or training schemes, it helps them to feel encouraged to engage in the traditional male societal roles. Indeed, we started to witness the increasing number of women in the leadership roles in the community.

Most women in this study described business activities by mining company as 'highly-political' in the sense that business and benefits can influence social and political roles of women in the community. Opportunities for them to engage in certain social activities created by mining company such as leading the village funds, running certain cultural activities can promote their political roles in the community. We learn that women in Vilabouly, under the Women Association, actively engage in land entitlement and the planning process of the company. By participating in the planning process, women in this community can actively engage in various political and cultural heritage with men.

"The company must engage us as part of the plan for the closure of its operation. We don't see the future of women and girls after this industry."

When discussed their future on social activities, some women are worried about losing their secured incomes or welfare from the industry. Ability to participate in social activities in the community is strongly related to women engagement with the mining industry.

\section{Theme 3: Equality through Health}

Health is complex; the result of a raft of socio-economic determinants. Women in Vilabouly are impacted by mining in all aspects of life. They are key to reversing disadvantage in their communities. Hiring women has greater welfare impact on families; they spend income in ways which increase child health and wellbeing. Most women in this study agreed that incomes from mining job help them to look after health and well-being of the family members. Good health can also give them some decision roles in the community health such as maternal scheme or health funds by the company.

In order to promote women in the underground operations, mining company seem to have lagged behind in an obvious respect; separate ablution facilities. Issues such as preparation for women (toilet, protection) is reported. Privacy is limited for women and this issue is badly affected their ability to work effectively.

They also raised some negative experiences related to the operation of mining company on their health. Most of them are related to stigma and discrimination and their low status in the mining industry.

"I am always under stress because of the work conditions. I feel that I have to work harder than my male colleagues and I know it is bad for my mental conditions." 


\section{"I feel that mining is not good for my health. It may not be right but I feel it."}

Most women participated in this study (94 per cent) agreed that mining companies should prepare a separate health scheme among male and female workers. They insist that prevention and treatment should be planned and costed on the basis of gender. Female workers require specific health services for genderspecific diseases and conditions (i.e cervical cancer), menopause, pregnancy, and violence against women. Study also found that women in this study manage their household income for the entire family. Most of them focus on some saving for the future. More importantly, most women accepted that their social status has increased because of their work and skills from the mining industry.

\section{Discussion}

Findings from this paper confirm that mining MNCs can create gender equality among men and women in many ways. Women in the mining community and MNCs experience different personal, family, health, and professional challenges and opportunities. We learn that representation of women in international mining industry can increase their opportunities in life. The relationship between economic and educational opportunities and transition in gender roles can be expected in the mining community.

There are three approaches that mining industry can contribute to the relationship between sustainable development and gender equality. They include (1) enterprise channel, an instrument where mining company create jobs and opportunities for women, (2) distribution channel, a mechanism where mining industry engage with various other stakeholders and allocate their resources to empower women to various educational, health and social schemes, and (3) government revenue, a mechanism where mining industry share its profits and knowledge with national and local government and promote long-term development in conjunction with the governmental instruments.

Mining company can play the role of "business as a development agent" (Blowfield, 2012) by deploying capital with the intention of delivering outcomes that contribute to development goals. This is dependent on giving primacy to the benefits of certain groups of community such as women, girls, people of low socioeconomic backgrounds, and being held for accountable for developmental outcomes. They will also need to promote understanding on the benefit of gender equality for all mining staff, community, and society.

However, the extent to which mining MNCs can be considered focus and accountable development agents remains limited due to the instrumental nature of development-oriented CSR programs which tend not to give primacy to development outcomes for intended beneficiaries (e.g. women, girls, people of different ethnic backgrounds). Hence, relationship between developmental programs by mining companies and community can be complex.

This study also confirms that sustainable development focusing on women in development assistance can achieve through the promotion of women's participation in key policies. If women do not participate in the key developmental policies by mining company, them the accessibility and effectiveness of equality mechanism will not be successful.

\section{References}

Asian Development Bank. (2012), PNG Country Gender Assessment, The Asian Development Bank: Manila.

Chaloping-March, M. (2006), Collaboration towards social sustainability: The case of a mining corporation, its surrounding communities, and local government in Benguet, Philippines, International Journal of Environment and Sustainable Development, Vol. 5, No. 2, pp. 109-118. 
Charmaz, K. (2008), Grounded theory in the 21st century: Applications for advancing social justice studies. In N. K. Denzin \& Y. S. Lincoln (Eds.), Strategies of qualitative inquiry (pp. 203-241). Thousand Oaks, CA, US: Sage Publications, Inc.

Dashwood, H. (2012), CSR norms and organizational learning in the mining sector, Corporate Governance, Vol. 12, No. 1, pp.118-138.

Grant, R.M. (2003), Strategic planning in a turbulent environment: evidences from oil major", Strategic Management Journal, Vol. 24 No. 2, pp. 491-517.

Hamann, R., (2004), Corporate social responsibility, partnerships, and institutional change: the case of mining companies in South Africa, Natural Resources Forum, Vol. 28, pp. 278-290.

Jutting, J. and C. Morrisson, J. Dayton-Johnson, and D. Dreschsler (2008), Measuring Gender (In) Equality, The OECD Gender, Institutions and Development Data Base, Switzerland.

Kemp, D; Owen, J, R; Gotzmann, N; Bond, C,J (2011), Just Relations and CompanyCommunity Conflict in Mining, Journal of Business Ethics, Vol. 101, pp. 93-109

Lahiri-Dutt, K.(20121), Digging women: towards a new agenda for feminist critiques of mining, Gender, Place \& Culture, Vol. 19, No.2, pp.193-212.

Mercier, L. \& Gier, J. (2007), Reconsidering women and gender in mining, History Compass, Vol. 5, No. 3, pp. 995-1001

Pimpa, N., Moore, T., Gregory, S., Tenni, B. (2015), Corporate social responsibility and mining industry in Thailand, World Journal of Management, Vol. 6, pp. 34-47.

Ruef, M., \& Scott, W. R. (1998), A multidimensional model of organizational legitimacy: Hospital survival in changing institutional environments, Administrative Science Quarterly, Vol. 43, No. 4, pp. 877-904.

Sharma, A. \& Kiran, R. (2013), Corporate social responsibility: driving forces and challenges, International Journal of Business Research and Development, Vol. 2, No. 1, pp.18-27.

Woetzel, J., Anu, M., Kevin, S., Oliver, T., Diaan-Yi L.and Michael, G.. (2018), The Power of Parity: Advancing Women's Equality in Asia Pacific. McKinsey. April. Available at: https://www.mckinsey.com/featured-insights/gender-equality/the-power-of-parityadvancing-womensequality-in-asia-pacific

Women in Mining (WIM) (2013), Mining for talent: a study of women on boards in the mining industry, Annual report by WIM and PWC, available at: https://www.pwc.com/gr/en/publications/assets/miningfor-talent.pdf

Women's Environment and Development Organization (WEDO) (2008), Gender and Governance Program, available at: www.wedo.org/programs.aspx?mode=gender.

World Economic Forum (2015), How mining affects women in the Democratic Republic of Congo, Mining and Metals Report. Available at: https:/www.weforum.org/agenda/2015/09/how-mining-affectswomen-in-the-democratic-republic-of-congo/

Yin, R.K. (1998), The Abridged Version of Case Study Research, Bickman, L. and Rog, D. J. (Eds.), Handbook of Applied Social Research Methods, Sage Publications, Thousand Oaks, pp. 229-259. 